Slavica Arsić, $\mathrm{MSc}^{1}$

Nataša Kljajić, $\mathrm{PhD}^{2}$

Marijana Jovanović, $\mathrm{MSc}^{3}$

Institute of Agricultural Economics, Belgrade
SCIENTIFIC REVIEW ARTICLE doi:10.5937/ekonomika1502103A Received: April 15, 2015 Accepted: May 6, 2015

\title{
UTILIZATION OF AN AGRICULTURAL LAND AS A BASIC CAPACITY FOR CORN AND WHEAT PRODUCTION IN SERBIA AND EX-YU COUNTRIES ${ }^{4}$
}

\begin{abstract}
Analysis of collected data from 2011, in structure of used agricultural land in Serbia shows that dominated plough land and gardens and meadows and pastures, until in smaller percentage are orchards and vineyards. Almost the same relation is noticed in other republics of former Yugoslavia (meadow and pastures are the most prevalent view of using the agricultural land in Slovenia, Macedonia, B\&H and Montenegro). Share of area under wheat notice smaller oscillation in all republics in the period 2008-2010, until yield per hectare is equalized for the same observed period. Share of area under corn in correlation with sown areas, for the period 2008-2012 is almost equalized for all republics. The average yield of corn per hectare records declining trend from 2008-2012, and it shows that by production Serbia is behind Slovenia and Croatia. Also, it was stated that world production of cereals grow in 2012 and in 2013, contributed by corn and wheat production in China, North America, European countries and former Soviet Union. Analysis of used land capacities is emphasized importance of land as a limited factor in production and base on that has given recommendation for alleviating problems in agriculture and food production. Conclusions are given based on calculation of percentages and their mutual comparisons for every country included in the research.
\end{abstract}

Key words: agricultural area, average yield per an area unit, corn, wheat, Serbia, ex-Yu countries.

JEL classification: Q10, Q19, P50

\footnotetext{
${ }^{1}$ slavica_a@iep.bg.ac.rs

2 natasa_k@iep.bg.ac.rs

3 marijana_j@iep.bg.ac.rs

${ }^{4}$ Paper is part of the research projects: III-46006 - Sustainable agriculture and rural development accomplishing the strategic objectives of the Republic of Serbia within the Danube region; funded by the Ministry of Education and Science of the Republic of Serbia for the period of 2011-2015.
} 


\title{
КОРИШЋЕЊЕ ПОЉОПРИВРЕДНОГ ЗЕМЉИШТА КАО ОСНОВНОГ КАПАЦИТЕТА ЗА ПРОИЗВОДЫУ КУКУРУЗА И ПШЕНИЦЕ У СРБИЈИ И ЗЕМЉАМА БИВШЕ ЈУГОСЛАВИЈЕ
}

\begin{abstract}
Апстракт
Анализом прикупьених података за 2011. годину у структури коришћеног пољопривредног земљишта у Србији доминирају оранице и баште и ливаде и пашьаци, док се у мањем проценту налазе воћњаци и виногради. Готово исти однос забележен је и у осталим републикама бивше Југославије (ливаде и пашњаци су заступљенији види коришћења пољопривредног землишта у Словенији, Македонији, БиХ и Црној Гори).Учешће површина под пшеницом бележи мање осцилащије у свим републикама у периоду 2008-2012 година, док је принос по хектару за исти посматрани период готово уједначен.Учешће повриина под кукурузом у односу на засејане површине за период 2008-2012. године је готово уједначена у свим републикама. Просечан принос кукуруза по хектару тренд опадања од 2008-2012 године и показује да се по производњи Србија налази иза Словеније и Хрватске. Такође је наведено да је производња житарииа у свету повећана у 2012 и 2012. години, чему је допринео род кукуруза и пшенице у Кини, Северној Америци, европским земљама и земљама бившег СССР-а. Анализом коришћених землишних капаџитета наглашен је значај земљишта као лимитирајућег фактора у производюи и дате су препоруке за ублажавање проблема у пољопривреди и производњи хране. Закључци су дати базирано на калкулачију процената и њихово међусобно поређење за сваку државу која је укључена у истраживање.
\end{abstract}

Кључне речи: пољопривредно земљиште, просечни принос по јединици повриине, пшеница, кукуруз, Србија, земље бивие Југославије

\section{Introduction}

Agricultural land is the greatest natural resource and the most important element of agricultural activities. From the economic point of view, it is a necessary condition for realization of production process in agriculture. While researching the capacities in agriculture, as well as the yield evaluation, the area of agricultural land represents a starting point (Subić et al, 2005.) Almost all indicators in agriculture analysis take into consideration the area of agricultural land, which are inevitable for perceiving the structure, relative share of some land categories in the total, as well as the analysis of sowed areas, when calculating yield etc.

Less for analytical and more for information purposes uses the comparison of total agricultural land with the total area of the state, resulting in a relative share, i.e. which percentage of land area is agricultural land. This ascertainment shows in which content the state is oriented to agricultural production.

In regard to the total area of Serbia, as well as in comparison with the other ex-Yu countries, the highest share has agricultural land. The percentage of agricultural land 
share in Serbia in regard to the state area is $57.6 \%$, in Croatia $23.4 \%$, in Slovenia $27.8 \%$, Macedonia 43.5\%, in B\&H 22.3\% and in Montenegro 37.3\%. Such high percentage of share in Montenegro is due to the fact that meadows and pastures, which mostly do not use, prevail in the land structure.

According to the latest census in 2012, the total area of used agricultural land in Serbia amounts 3,355.859 ha, of which family husbandries use around $84 \%$ and the rest $16 \%$ - companies and cooperatives. In relation with total agricultural area, the total number of family husbandries in Serbia uses 5.3 hectares of agricultural land. However, of utilized agricultural area $(2,816.424 \mathrm{ha})$, used by 628,555 family husbandries, in average they use 4.5 ha of agricultural land. The average of arable land in Montenegro is 6.3 ha, in Croatia 5.6 ha and Slovenia 6.5 ha per a husbandry, while the average in the European Union is 17.9 hectares.

According to Statistical Yearbook of Serbia (2012) in accordance to the analysis of agricultural land in five regions in Serbia, in Vojvodina uses 1,747 thousand hectares or $34.6 \%$ of totally used agricultural land in Serbia. Although the largest number of agricultural husbandries is in the region of Sumadija and West Serbia 262,531, they use only $31.4 \%$, the region of South and East Serbia uses $29.8 \%$ and the smallest area of totally utilized agricultural land uses the Belgrade region (4.2\%).

The biggest area of agricultural land is used for cereals production (wheat, rye, oats, maize, millet and broomcorn), which occupy around $63 \%$ of the total sown areas. Of all particularized cereals, maize is the most represented crop with over 1.2 million sown hectares, in the second place is wheat with around half a million hectares. Due to large sown areas, cereals are among sectors with the highest value of primary production of around a milliard euro per a year, which additionally increases by further processing (Serbian National Program of Agriculture 2009-2011).

According to the report of the United Nations for Food and Agriculture, FAO (February 2013), production of cereals in 2012 in the world was increased for 20 million tons in regard to data in December, but it was still $2 \%$ lower production than in the year 2011. Good yield of maize in China, North America, European countries and ex-SSSR countries affected the most total increase.

The harvested area of all crops in the world in the past 20 years has ranged from 825 to 887 million hectares, while wheat has produced on areas which varied from 209 to 232 million hectares, which has been approximately $26 \%$ of total harvested areas. In our country, the share of areas under wheat is significantly less and ranges under $20 \%$, which is not favorable, from the aspect of properly used land.

At the European level, Serbia represents a significant producer of cereals and also the biggest regional producer, regarding the sown areas under maize is on the sixth place in Europe and regarding wheat on the twelfth place. Regarding the maize production Serbia is in the $15^{\text {th }}$ place in the world.

\section{Material and method of work}

The research in the paper comprises the analysis of available land capacities according to a method of use, production parameters: area, total production and yields of more important crop products, in this case of wheat and maize. By the analysis of statistical data for Serbia and the ex-Yu countries, there the analysis of land resources structure will be made, 
according to a method of use of agricultural land, with a special reference to the structure and the method of use of plough land. In regard to a fact that in the structure of plough land dominate cereals, there the percentage data on areas, size of production and yields of wheat and maize in Serbia were presented, which were compared with the countries of ex-Yugoslavia. The data were arranged in tables, where a five-year data series was enclosed, started from 2008 to 2012, as well as the comparison of data with those in the year 2013, for the purpose of determination of the basic economic indicators of wheat and maize production performance.

For the statistical calculation of percentages and their mutual comparisons were used data from the statistical yearbooks for all mentioned countries, as well as data from the United Nations Organization for Food and Agriculture (FAO), professional foreign and national literature.

\section{Structure of agricultural land in serbia and ex-yu countries}

In accordance to the authors Kljajić, Arsić and Mijajlović (Tranzicija, 2012), by categories of use, in structure of agricultural land is evidently high share of crop acreages in Serbia (83\%). Observed in average for the period $2000-2009 ; 65.5 \%$ is plough land, $4.8 \%$ orchards, $1.4 \%$ vineyards, $12.0 \%$ meadows and $16.3 \%$ pastures of the total area of arable land which is on average 5,086.000 ha.

In the paper was presented the structure of agricultural land in Serbia and the ex-Yugoslav republics, where is going to be perceived a difference in the structure of agricultural land use and the percentage share per categories in the total agricultural land. Considering that the structure of agricultural land changes slowly, data for just one year are sufficient to recognize the most important relations. The year 2011, shown in the table 1, was used for this purpose in processing of statistical data.

Table 1. Land structure in the year 2011 and the percentage share of categories in the total agricultural land

000 ha

\begin{tabular}{|l|r|r|r|r|r|r|}
\hline & \multicolumn{1}{|c|}{ Serbia } & \multicolumn{1}{c|}{ Croatia } & Slovenia & Macedonia & B\&H & Montenegro \\
\hline Agricultural land, in total & 5052 & 1326 & 4581 & 1120 & 1141 & 515 \\
\hline Plough land and gardens & 3294 & 892 & 168 & 415 & 390 & 45 \\
\hline Share \% & $\mathbf{6 5 . 1}$ & $\mathbf{6 7 . 3}$ & $\mathbf{3 6 . 7}$ & $\mathbf{3 7 . 1}$ & $\mathbf{3 4 . 2}$ & $\mathbf{8 . 7}$ \\
\hline Orchards & 240 & 32 & 26 & 14 & 44 & 12 \\
\hline Share \% & $\mathbf{4 . 7}$ & $\mathbf{2 . 4}$ & $\mathbf{5 . 8}$ & $\mathbf{1 . 2}$ & $\mathbf{3 . 8}$ & $\mathbf{2 . 3}$ \\
\hline Vineyards & 56 & 32 & 16 & 21 & 5 & 4 \\
\hline Share \% & $\mathbf{1 . 1}$ & $\mathbf{2 . 4}$ & $\mathbf{3 . 6}$ & $\mathbf{2 . 0}$ & $\mathbf{0 . 4}$ & $\mathbf{0 . 8}$ \\
\hline Meadows and pastures & 1466 & 346 & 2626 & 669 & 699 & 450 \\
\hline Share \% & $\mathbf{2 9 . 1}$ & $\mathbf{2 6 . 1}$ & $\mathbf{5 7 . 3}$ & $\mathbf{5 9 . 7}$ & $\mathbf{6 1 . 5}$ & $\mathbf{8 7 . 4}$ \\
\hline Other & - & $\mathbf{1 . 8}$ & $\mathbf{3 . 4}$ & - & - & 0.2 \\
\hline
\end{tabular}

Source: SORS (2012) Statistical Yearbook of Serbia 2012; CBS (2013): Statistical Yearbook of Republic of Croatia 2013; SORS (2013): Statistical Yearbook of the Republic of Slovenia 2013; SSO (2014): Statistical Yearbook of Republic of Macedonia, 2014; Institute for Statistics B\&H (2012): FB\&H in figures 2012; Montenegro Statistical Office (MONSTAT) (2012): Statistical Yearbook 2011. 
In the table 1 we can see that more than a half of agricultural land in Serbia is plough land and gardens, which point out to a high share of areas which can be used for intensive production of different crops. Besides the areas under plough land and gardens Croatia has the approximate share of other forms of agricultural land in the total one, as well as Serbia has. The conclusion is that Serbia and Croatia have a similar structure of agricultural land. Unlike Serbia and Croatia, which are characterized by a high share of plough land and gardens, Bosnia and Herzegovina, Macedonia and Slovenia are characterized by a high share of areas under meadows and pastures. The highest share of meadows and pastures has Montenegro, $87.4 \%$. Due to poor configuration of the terrain and poor quality of soil, the land in all these countries is characterized by high share of meadows and pastures Those are predominantly hilly terrains, as well as mountainous terrains which have an effect on a fact that major part in the total agricultural land makes the areas under meadows and pastures which cannot be used for other purposes, i.e. the conversion to arable land (especially meadows).

In Serbia the percentage in the total agricultural land under plough land amounts $65.1 \%$. Regarding plough land use $(3,294$ thousand hectares) the percentage of totally sown areas $(3,067$ thousand hectares) in Serbia is $93.1 \%$, of which the largest areas are under cereals $(62.3 \%)$, industrial crops $(14 \%)$, vegetable crops $(8.9 \%)$ and forage crops (14.8\%). However, there is a part of uncultivated arable land and fallows 7\% (2011). According to calculation in the year 2012 in Serbia were 3,282 thousand hectares under plough land and gardens, therefore their share in the total used agricultural land amounts $65.0 \%$ at the state level. Of the totally sown arable land (3,060 thousand hectares) which is $93.2 \%$, the largest sown areas are under cereals with share of $62.7 \%$. Comparing the years 2011 and 2012, there is decrease of areas under plough land, as well as total sown areas, but areas under cereals increase for $0.4 \%$.

In Croatia in the year 2011, of the total used agricultural area, areas under plough land amount $67.3 \%$, cereals $64.5 \%$, industrial crops $14.3 \%$, forage crops $14.5 \%$, in total $93.3 \%$ of sown plough land and the rest (6.7\%) are sown crops in arable land. There is an increase of arable land in regard to the previous year for $1.2 \%$ in 2012 , so it is $67.9 \%$ in the totally used agricultural area, and therefore increased also areas under cereals, $67.7 \%$ of arable land (CBS (2013): Statistical Yearbook of Republic of Croatia 2013).

As far as Slovenia in the year 2011 arable land occupies around $36.7 \%$ of the total agricultural land, in the structure of sown areas cereals are $55.8 \%$, industrial crops 7,3 forage crops $31,5 \%$, which is in total $94.6 \%$ and the rest $(5.4 \%)$ are others sown areas. The calculation for 2012 showed that there was increase of totally sown areas for $4.7 \%$. However, although there is increase of areas under plough land for $1.7 \%$, their share in totally sown areas decreases to $35.8 \%$, but the percentage in the structure of sown areas under cereals increases to $57.3 \%$ within the arable land (SORS (2013): Statistical Yearbook of the Republic of Slovenia 2013).

In Macedonia in 2011 arable land had occupied $45.6 \%$ of the total agricultural area, while plough land and gardens had occupied $81.2 \%$ of the total arable land. Regarding plough land, cereals occupy $39.3 \%$ of area (within totally sown areas cereals occupy $58.8 \%$ ), industrial crops $6.7 \%$, vegetable $12.3 \%$ and crops $8.4 \%$, while $33.3 \%$ are nursery beds, fallows and uncultivated fields. According to statistical data of the Republic of Macedonia (Statistical Yearbook of the Republic of Macedonia, 2014) the calculation for the years 2012 and 2013 was showed that there was decrease of arable land for 
around $1.0 \%$. Nevertheless, in 2013 there is increase of sown areas for $1.4 \%$ in regard to 2011. As for the percentage share in totally sown areas for the year 2013, cereals occupy $59.8 \%$, which means that there is increase in regard to the previous two years.

In 2011, Bosnia and Herzegovina had $61 \%$ of crop acreage in the total agricultural area, of which $56 \%$ are plough land, sown areas within the plough land amounts $50.2 \%$, of which the largest area occupy cereals $43 \%$, industrial crops $1.0 \%$, vegetable crops $22.4 \%$ and forage crops $33.6 \%$. Other crops, fallows and uncultivated fields occupy the area of $49.7 \%$. Considering that crop acreage in the year 2012 had increased for $3.3 \%$ in regard to the previous year, the share of plough land in the total crop acreage had amounted $55.1 \%$. Within arable fields cereals occupy $21.7 \%$ and in total sown areas their share amounts $44.1 \%$, which means that there is increase of sown areas under cereals (SSO (2014): Statistical Yearbook of Republic of Macedonia).

The total agricultural area in Montenegro occupies 515,740 ha, of which plough land and gardens occupy $24.2 \%$ of all crop acreage, while the total sown area within plough land is $70.3 \%$, of which cereals are $16.1 \%$, industrial crops $0.4 \%$, vegetable crops $58.7 \%$ and forage crops $24.8 \%$. Fallows and uncultivated fields occupy $29.7 \%$. The calculation for the year 2012 was shown that the share of plough land in crop acreage had remained unchanged in regard to the previous year. However, although the share of total sown area in crop acreage has increased to $71.1 \%$ the share of sown cereals has decreased to 15.7\% (Montenegro Statistical Office (MONSTAT) (2012): Statistical Yearbook 2011.).

\section{Wheat production}

Wheat is one of the very important agricultural products due to its multiple uses. It uses for production of flour, as very important product for baking and food industry, as well as for the development of livestock production. The price of flour depends directly on the price of wheat, and thereby also of many final products, primarily bread as a basic food. In those years when yields are bad, i.e. when the total produced amount is under the acceptable one, the price of wheat increases which reflects to the above mentioned products. It is very important role of the state which should intervene in those years with poor yields, from the stock reserves, which form in a time when yields are good. The role of the state is also to have an effect on size of production by its measures of agrarian policy, in order to provide uniformly and stable supply of the market, as well as to have a positive effect on a phenomenon of more significant decrease of production, as it is the case in our country (SEEDEV team, 2012)

In Serbia, on approximately 500 thousand hectares produces annually around 2 million tons of wheat. The largest share in Serbia of areas under wheat for the year 2012 had the region of Vojvodina (49.3\%), where produces around a million ton of wheat on the area of 237 thousand hectares. In the year 2013 the percentage share for the region of Vojvodina was amounted $52.2 \%$ of sown areas under wheat in regard to total sown areas in Serbia. Together with the Belgrade region share (4.9\%), Serbia-North occupies sown area of $57 \%$. Serbia-South occupies $43 \%$, where the region of South and East Serbia has the percentage share of sown area under wheat of $25.2 \%$ and the region of Šumadija and West Serbia $17.8 \%$. 
At the beginning would be useful to perceive the share of areas under wheat in regard to the total sown areas. Except for Serbia also data for the ex-Yu countries will be presented, which will be compared to.

According to the table 2 we can notice that, when it comes to the ex-Yu countries, Montenegro has the lowest share of areas under wheat in regard to total sown areas. This percentage is a bit higher than in Bosnia and Herzegovina in comparison to Montenegro, but much lower in comparison to Croatia, Slovenia and Serbia, where areas under wheat occupy almost one fifth of the total sown areas. These relations are only regarding the percentage share and they show the percentage of sown areas used for wheat sowing. In that way, we can see production orientation of producers and the state regarding some specific agricultural products production. Factors which affect this are numerous. That is to say, crop acreage can be used for sowing of numerous crops (maize, oats, barley, etc.) and choice, i.e. orientation of producers will depend on conditions in which do business (purchasing price, subsidy, price of seed and fertilizers).

Table 2 Share of areas under wheat in regard to total sown areas in ha and share in \% (000 ha)

\begin{tabular}{|c|l|l|l|l|l|l|}
\hline Countries & Years & 2008 & 2009 & 2010 & 2011 & 2012 \\
\hline \multirow{5}{*}{ Serbia } & Wheat-sown area & 488 & 568 & 493 & 494 & 481 \\
\cline { 2 - 7 } & Total sown area & 3099 & 3089 & 3066 & 3067 & 3060 \\
\cline { 2 - 7 } Croatia & Share in\% & $\mathbf{1 5 . 7}$ & $\mathbf{1 8 . 4}$ & $\mathbf{1 6 . 1}$ & $\mathbf{1 6 . 1}$ & $\mathbf{1 5 . 7}$ \\
\hline \multirow{5}{*}{ Slovenia } & Wheat-sown area & 156536 & 180376 & 168507 & 149797 & 186949 \\
\cline { 2 - 7 } & Total sown area & 855416 & 863023 & 899594 & 892221 & 903508 \\
\cline { 2 - 7 } & Share in\% & $\mathbf{1 8 . 3}$ & $\mathbf{2 0 . 9}$ & $\mathbf{1 8 . 7}$ & $\mathbf{1 6 . 8}$ & $\mathbf{2 0 . 7}$ \\
\cline { 2 - 7 } & Wheat-sown areas & 35413 & 34534 & 31946 & 29665 & 34586 \\
\cline { 2 - 7 } & Total sown area & 180303 & 175189 & 170144 & 168744 & 171668 \\
\hline \multirow{5}{*}{ Macedonia } & Share in\% & $\mathbf{1 9 . 6}$ & $\mathbf{1 9 . 7}$ & $\mathbf{1 8 . 7}$ & $\mathbf{1 7 . 6}$ & $\mathbf{2 0 . 1}$ \\
\cline { 2 - 7 } & Wheat-sown areas & 86890 & 88256 & 79946 & 78588 & 79750 \\
\cline { 2 - 7 } & Total sown area & 424 & 420 & 415 & 415 & 414 \\
\hline & Share in\% & $\mathbf{2 0 . 5}$ & $\mathbf{2 1 . 0}$ & $\mathbf{1 9 . 2}$ & $\mathbf{1 9 . 0}$ & $\mathbf{1 9 . 2}$ \\
\cline { 2 - 7 } & Wheat-sown areas & 19604 & 19011 & 17282 & 17836 & 18866 \\
\cline { 2 - 7 } & Total sown area & 198 & 192 & 189 & 196 & 195 \\
\cline { 2 - 7 } & Share in\% & $\mathbf{1 0 . 0}$ & $\mathbf{1 0 . 0}$ & $\mathbf{9 . 1}$ & $\mathbf{9 . 1}$ & $\mathbf{9 . 6}$ \\
\hline \multirow{5}{*}{ Montenegro } & Wheat-sown areas & 826 & 846 & 734 & 756 & 773 \\
\cline { 2 - 7 } & Total sown area & 31317 & 31886 & 31025 & 32149 & 32475 \\
\cline { 2 - 7 } & Share in\% & $\mathbf{2 . 6}$ & $\mathbf{2 . 6}$ & $\mathbf{2 . 3}$ & $\mathbf{2 . 3}$ & $\mathbf{2 . 4}$ \\
\hline
\end{tabular}

Source: Calculations based on data from SORS (2012) Statistical Yearbook of Serbia 2012; CBS (2013): Statistical Yearbook of Republic of Croatia 2013; SORS (2013): Statistical Yearbook of the Republic of Slovenia 2013; SSO (2014): Statistical Yearbook of Republic of Macedonia, 2014; Institute for Statistics B\&H (2012): FBiH in figures 2012; Montenegro Statistical Office (MONSTAT) (2012): Statistical Yearbook 2011.

The previous table 2 was also helpful in perceiving the changes in this share for the period 2008-2012. We can notice that in Serbia the percentage of this share has constantly decreasing and in the year 2012 it had achieved the level from the year 2008 $(15.7 \%)$, which meant that there were less areas under wheat in comparison to the total sown areas. In the year 2012 the production of 1.910,914 tons of wheat was realized on 
481 thousand hectares, which means that production of wheat is for $8.0 \%$ lower than the one realized in the year 2011. However, in 2013 the wheat production had increased to $17.5 \%$ in regard to the total sown areas under wheat, wherefore the production of wheat had increased for $40.8 \%$ in regard to the year 2012 and yield per a hectare had amounted 4.8 tons. In Bosnia and Herzegovina this percentage is very stable, unlike Montenegro where it records a slight decline. In Croatia, this share records small oscillations, but in 2012 it almost was achieved the level from the year $2009(20.9 \%)$ to $20.7 \%$, while there was increased sown area under wheat for $24.8 \%$ in regard to the previous year 2011. Slovenia had also oscillations in these years, but in 2012 was present increase; it had achieved the share of $20.1 \%$ or for $16.6 \%$ more sown areas in regard to the previous year 2011. As for Macedonia, there was a decrease in share of sown areas under wheat. In the year 2012 the share was for $8.2 \%$ lower than in the year 2008 and in 2009 for $9.7 \%$, but Macedonia was nevertheless in the third place behind Croatia and Slovenia regarding the percentage share of sown areas under wheat in the last observed year 2012, because there was an increase of sown areas for $1.5 \%$ in regard to the previous year 2011 .

Besides the sown areas, which represent the first factor to affect the quantity of wheat that is going to be harvested during the year, yield per a hectare is maybe even more important factor. The yield can be defined as the quantity of wheat that has been harvested, expressed in kilograms or tons per one hectare of sown area. Data on crop yield are so called a net granary yield of normal humidity, i.e. the yield after deduction of losses which appear in ripening, harvesting, transporting or threshing season.

Many factors have an effect on the yield, such as: soil quality, seed quality, quantity of fertilizers, method of soil cultivation, etc. Very important factor, besides those mentioned ones, are also climatic conditions. That is to say, it is very important what were the weather conditions, if there were enough rainfalls, what was the winter like, if there was bad weather (natural disasters), as hail, etc. All cited factors determine significantly the quantity of wheat which is going to be harvested. In the following table 3 presents data on yield per a hectare in Serbia and the ex-Yu countries.

Table 3. Average yield of wheat per a hectare in tons for the period 2008-2012

\begin{tabular}{|l|c|c|c|c|c|c|}
\hline Year & Serbia & Croatia & Slovenia & Macedonia & B\&H & Montenegro \\
\hline 2008 & 4.3 & 5.5 & 4.5 & 3.5 & 3.8 & 3.4 \\
\hline 2009 & 3.6 & 5.2 & 3.9 & 2.6 & 3.9 & 3.6 \\
\hline 2010 & 3.4 & 4.0 & 4.8 & 3.0 & 2.9 & 3.3 \\
\hline 2011 & 4.2 & 5.2 & 5.2 & 3.3 & 3.8 & 3.2 \\
\hline 2012 & 4.0 & 5.3 & 5.4 & 3.0 & 3.6 & 3.2 \\
\hline Average & 3.9 & 5.0 & 4.7 & 3.0 & 3.6 & 3.3 \\
\hline
\end{tabular}

Source: SORS (2012) Statistical Yearbook of Serbia 2012; CBS (2013): Statistical Yearbook of Republic of Croatia 2013; SORS (2013): Statistical Yearbook of the Republic of Slovenia 2013; SSO (2014): Statistical Yearbook of Republic of Macedonia, 2014; Institute for Statistics B\&H (2012): FBiH in figures 2012; Montenegro Statistical Office (MONSTAT) (2012): Statistical Yearbook 2011.

In the table 3 were given data for five years, which is sufficiently long period to eliminate differences in yield, occurred due to influences of different weather conditions. 
Considering that each year the ratio in yield is almost the same, there was calculated the yield for that period, owing to easier comparison. According to the presented average yield for five years, the highest yield per a hectare has Croatia and follows Slovenia. In comparison with them, Serbia lags behind significantly, but it has a higher yield in regard to Bosnia and Herzegovina, Montenegro and Macedonia. Reasons that can lead to differences in yield are numerous. Owing to similar soil configuration and climatic conditions, the greatest impact to the yield has the quantity of fertilizers and the method of soil cultivation.

Since the yield per a hectare in that period was rather homogenous, this means that totally produced quantity of wheat reduces constantly. In case that needs for wheat stay at the same level, and the production decreases, it will first of all decrease export and then also forming a higher price of this product on the market, which further affects the increase of prices of other products.

Wheat production in the world in 2008/2009 had recorded a top production of 682.7 million tons on the area of 225.0 million hectares, which was the second largest yield in the world. However, in 2009/2010 the production of wheat was decreased for 5.3 million tons (677.4 million tons) in regard to the previous top production of wheat. The wheat production was decreased in USA (from 68.0 to 60.3 million tons), Canada (from 28.6 to 26.5 million tons), Russia (from 63.4 to 61.5 million tons) and Ukraine (from 25.3 to 21.1 million tons) and was increased in China, India, Australia and Kazakhstan. Within the European Union the biggest producer of wheat is France with annual production of over 36 million tons, than follow Germany with 25 million tons, Great Britain with 15 million tons, Poland 9 million tons, Romania 6 million tons, and Denmark and Hungary with over 5 million tons.

\section{Maize production}

The areas favourable for growing maize in Serbia are plough land in lowland areas (around 70\%) and 30\% in highland and mountain areas; in our conditions, production of maize is of great significance. Maize is a crop which is the most important for livestock feeding. It uses in all branches of livestock in specific phases of livestock feeding. In Serbia and the other ex-Yu countries too, orientation to maize production has always been very represented in agricultural cooperatives, as well as the individual producers. Individual farmers decide in most of the cases for maize or wheat sowing, while other crops (oats, barley, rye, sunflower, etc.) are less represented. With over 1.2 million sown hectares in Serbia maize has been the most represented crop in production structure, while it participates with $42.1 \%$ in total sown areas under cereals. Significant domestic and foreign demand for maize is one of the reasons for such large sown areas. Besides, it also affects development of market chains and safe sale. Availability of mechanization and labor, poor investments for storing on their own farms, favorable climatic conditions for this production, as well as the fact that it belongs to a group of crops which contribution in forming the reimbursement margin of a husbandry is higher than its share in optimal structure of sowing (Todorović and Muncan, 2009).

When it comes to areas under maize, the share is pretty constant, unlike wheat where there are significant oscillations. Areas under maize have been a homogenous year 
in year out; there were not significant aberrations in any of the years. In the observed period from 2008 to 2012 we cannot see more significant changes, in the whole period the share of areas under maize was homogeneous, with negligible oscillations.

In this case, more interesting data than the change of share is a size of that share in some countries. It is interesting that almost a third of sown areas in Croatia are the areas under maize. It follows that Croatian producers are very much oriented toward maize production. In Slovenia the share of these areas is also high, but significantly lower in comparison to areas in Croatia. The same is with areas in Bosnia and Herzegovina, where the areas under maize are twice as much as the areas under wheat. Serbia, for example, has a significantly higher share of these areas (42.1\%) in comparison to all previously mentioned countries in the last observed year (Table 4).

Table 4 Share of areas under maize in regard to total sown areas (in 000 ha)

\begin{tabular}{|c|c|c|c|c|c|c|}
\hline Countries & Years & 2008 & 2009 & 2010 & 2011 & 2012 \\
\hline \multirow{3}{*}{ Serbia } & Maize-sown area & 1277 & 1211 & 1235 & 1262 & 1288 \\
\hline & Total sown area & 3099131 & 3089 & 3066 & 3067 & 3060 \\
\hline & Share in $\%$ & 41.2 & 39.2 & 40.3 & 41.1 & 42.1 \\
\hline \multirow{3}{*}{ Croatia } & Maize-sown area & 314062 & 29691 & 29676 & 29676 & 299161 \\
\hline & Total sown area & 855416 & 863023 & 897416 & 892221 & 903508 \\
\hline & Share in $\%$ & 36.7 & 34.4 & 33.1 & 33.1 & 33.1 \\
\hline \multirow{3}{*}{ Slovenia } & Maize-sown area & 43698 & 38611 & 36433 & 40185 & 39166 \\
\hline & Total sown area & 180303 & 175189 & 170149 & 168744 & 171668 \\
\hline & Share in $\%$ & 24.2 & 22.0 & 21.4 & 23.8 & 22.8 \\
\hline \multirow{3}{*}{ Macedonia } & Maize-sown area & 31582 & 32737 & 28644 & 29390 & 29198 \\
\hline & Total sown area & $(286)$ & (293) & $(277)$ & $(277)$ & $(276)$ \\
\hline & $\begin{array}{l}\text { Učešće u \% } \\
\text { Share in } \%\end{array}$ & (11.0) & (11.2) & (10.3) & $(10.6)$ & (10.6) \\
\hline \multirow{3}{*}{ B \& H } & Maize-sown area & 50023 & 48685 & 46714 & 48620 & 48558 \\
\hline & Total sown area & 198056 & 19200 & 189164 & 196925 & 196799 \\
\hline & Share in $\%$ & 25.2 & 25.3 & 25.0 & 25.0 & $25.0 / 24.6$ \\
\hline \multirow{3}{*}{ Montenegro } & Maize-sown area & 2712 & 2664 & 2734 & 2798 & 2798 \\
\hline & Total sown area & 31.317 & 31.886 & 31.025 & 32.149 & 32475 \\
\hline & Share in $\%$ & 8.7 & 8.4 & 8.8 & 8.7 & 8.6 \\
\hline
\end{tabular}

Source: Calculation of authors according to data from SORS (2012) Statistical Yearbook of Serbia 2012; CBS (2013): Statistical Yearbook of Republic of Croatia 2013; SORS (2013): Statistical Yearbook of the Republic of Slovenia 2013; SSO (2014): Statistical Yearbook of Republic of Macedonia, 2014; Institute for Statistics B\&H (2012): FBiH in figures 2012; Montenegro Statistical Office (MONSTAT) (2013): Statistical Yearbook 2012.

The areas sown with maize in the last observed year (2012) in Serbia are for 2\% largest than in the past year, however, the production of maize was for $45.5 \%$ lower than in the year 2011, so the yield per a hectare was also lower and it was amounted around $3.0 \mathrm{t} / \mathrm{ha}$. According to the SO RS data for the year 2013 we come to the results which point out to decrease of share of areas sown with maize for $7.3 \%$ in regard to the previous year. In regard to total sown areas of 3,054 thousand hectares, the share of sown areas under maize was $39.1 \%$, or close to the average in 2009 . Within the sown areas under 
cereals the share of maize is $62.2 \%$ in the year 2013. Around 800 million tons of maize produce in the world, while Serbia takes $10^{\text {th }}$ place in the world regarding maize production, and in Europe it is in sixth or seventh place.

Table 5. Average yield of maize per a hectare in tons for the period 2008-2012

\begin{tabular}{|l|c|c|c|c|c|c|}
\hline Year & Serbia & Croatia & Slovenia & Macedonia & B\&H & Montenegro \\
\hline 2008 & 4.8 & 8.0 & 7.3 & 4.0 & 4.6 & 3.6 \\
\hline 2009 & 5.3 & 7.4 & 7.8 & 4.7 & 4.9 & 3.8 \\
\hline 2010 & 5.9 & 7.0 & 8.5 & 4.5 & 4.4 & 3.8 \\
\hline 2011 & 5.1 & 5.7 & 8.7 & 4.3 & 4.2 & 4.2 \\
\hline 2012 & 3.0 & 4.3 & 7.1 & 4.0 & 3.0 & 3.2 \\
\hline Average & 4.82 & 6.48 & 7.88 & 4.3 & 4.2 & 3.7 \\
\hline
\end{tabular}

Source: SORS (2012) Statistical Yearbook of Serbia 2012; CBS (2013): Statistical Yearbook of Republic of Croatia 2013; SORS (2013): Statistical Yearbook of the Republic of Slovenia 2013; SSO (2014): Statistical Yearbook of Republic of Macedonia, 2014; Institute for Statistics B\&H (2012): FBiH in figures 2012; Montenegro Statistical Office (MONSTAT) (2012): Statistical Yearbook 2011.

According to the calculation of the average yield of maize per a hectare (Table 5) for the observed period (2008-2012) we can notice that Slovenia is on the first place with round $7.9 \mathrm{t} / \mathrm{ha}$, although there are specific oscillations in hectares of sown areas, but yields are higher. The second one by the yield average is Croatia which has around $6.5 \mathrm{t} / \mathrm{ha}$ of maize. In the year 2013, on 290,000 hectares, was produced 1,914.000 tons of maize in Croatia, which is $47 \%$ more than in the previous year, which show data of Croatian Bureau of Statistics on areas and production of cereals and other crops. According to the same source the realized average production of maize per a hectare in 2013 was amounted 6.6 tons, which was much higher yield than in 2012, when it was amounted $4.3 \mathrm{t} /$ ha, although there was for $3 \%$ less sown areas under maize. Serbia is in the third place $(4.8 \mathrm{t} / \mathrm{ha})$ regarding the average yield of maize for the observed period. In the year 2010 maize in Serbia had yieled a bumper crop with over seven million tons of yield $(7,207.191)$ on 1.23 million hectares, when the yield was highest, 5.9 t/ha (SORS, 2011). If we observe by the regions in regard to the Republic of Serbia the share of sown areas under maize (2013) is the largest in the region Serbia-North with $62 \%$. Here belong the Belgrade region with $4.5 \%$ (with a yield of $4.1 \mathrm{t} / \mathrm{ha}$ ) and the region of Vojvodina with the largest share of $57.5 \%$, which has the largest share of $5.8 \mathrm{t} / \mathrm{h}$ of maize. Then follows Serbia-South with the share of $38 \%$, where the regions of Sumadija and West Serbia participate with $20.7 \%$ and the yield per a sown area of $4.1 \mathrm{t} / \mathrm{ha}$ and the region of South and East Serbia which takes part with $17.3 \%$ and the yield of $3.4 \mathrm{t} / \mathrm{ha}$.

Macedonia with $4.3 \mathrm{t} / \mathrm{ha}$ and Bosnia and Herzegovina with $4.2 \mathrm{t} / \mathrm{ha}$ have approximately the same average yield of maize per a hectare in the observed period. Montenegro has the lowest average and it amounts $3.7 \mathrm{t} / \mathrm{ha}$ (table 5). That is why they are the most important buyers of maize from Serbia. Most of the Serbian maize surpluses end on the European Union market, then in the surrounding countries, as Bosnia and Herzegovina, Macedonia, Montenegro and Albania, even on the markets of South Korea and Japan.

In the season 2012/2013, world stocks of maize, according to the United States Department of Agriculture, had decreased for 11\% in regard to the level in 2011/2012 to 
the lowest level in six-year-lasting period, primarily due to drought in the U.S.A., as well as for $2.6 \%$ less maize in the European Union. Nevertheless, the European Commission had reduced prognosis for maize yields in the European Union in the year 2012, after the great heat and little precipitation in South-East Europe in August and in the beginning of September. The projected decline in yields of $20 \%$ in the EU was a consequence of a great decline in yields in Hungary, Bulgaria, Romania and Italy.

Maize as a crop grows mostly in the United States of America. For the period 2013/2014, the International Grains Council has increased a global prognosis of maize production for three million tons to 945 million, or for $10 \%$ in regard to the period $2012 / 2013$, regarding that there was a increase of maize production in the U.S.A. (www. agrarije.com, visited on $26^{\text {th }}$ February 2015).

\section{Problem of agricultural production in Serbia}

Besides land, as a basic factor of agricultural production, significant factor are also employees in agriculture as well as an agricultural inventory. That is to say, a good land is a precondition of high quality and productive production, but it is not the only one. By a correct cultivation the use of high quality fertilizers in sufficient quantities and by apply of modern knowledge considerably affect the yields. As for the first condition, Serbia has a high quality land. In central Serbia land can be characterized as land of medium quality, while land in Vojvodina is extremely fertile. However, when it comes to other factors, the problems appear in form of decreasing a number of employees in agriculture, poor working conditions, bad agrarian policy of the state and many other factors which have an effect on decreasing orientation of people toward agricultural production. Incomes which can be realized in other activities have been usually higher than in agriculture, and it also has an impact. Decrease of employees in agriculture has been mostly caused by a decreasing number of rural population, which have been carriers of agricultural production, and it also had affected the average age of people (over 60 years of age), as incapable to work. Decreasing a number of rural populations could not be a problem per se if development of agriculture is on a higher level. In countries where there is a high share of areas cultivated by big landowners and agricultural organizations and where has been applied modern mechanization, there is a low share of employees in agriculture. Regarding that in our country dominate individual producers and households, decreasing number of employees in agriculture also means decreasing of agricultural production. As for mechanization which uses in agriculture, it decreases, especially in the last years, while mechanization is quite obsolete and therefore inefficient. Investments in mechanization are minimal, and the reason is a high price of mechanization and poor support of the state to agricultural producers in the amount of subsidies for purchasing new mechanization, on the other hand. We also know that high quality mechanization is a precondition of productive and competitive production.

It is well known that the quantity of fertilizers and active substances which use per 1 ha of arable land affect directly, as on the quality of soil (reduction of weed, increase of fertility), as well as on yields. Satisfying consumption of fertilizers and preparations per 1 ha is only present in bigger agricultural organizations, which have more financial resources. Regarding individual producers, they have lower consumption of fertilizers. In that sense, the role of the state is very important. 
It means that, besides soil, the employees in agriculture, mechanization and use of fertilizers and active substances are the factors which substantially determine the quality of a product and yield, and therefore was paid attention to them. Finally, it is important to mention one factor on which cannot be influenced, and those are weather conditions. An agricultural producer has to do everything that is in his power to provide conditions for high yields, but weather conditions will judge and this is when a man is powerless.

\section{Conclusion}

In previous presentations were mentioned the most significant characteristics of land capacities in our country and methods of their use. There can be noticed that the structure of agricultural land is constant, which is logical too, because this value is tardily variable. That is why the structure analysis wasn't done for longer time period, because there were no significant changes. Opposite to it, a comparison of the structure between the countries is much more interesting. A difference in structure among the countries could notice, and causes were discussed. Since the scope of work was limited, there was impossible to make more detailed analysis of overall agricultural land structure, but an accent was put on the structure of plough land (first of all, because they occupy the largest area). Within the plough land, there was analysed in detail the production of wheat and maize, as products with the highest share in agricultural production. There was useful to compare the share of these areas with those in the surrounding countries. Very interesting and useful were data on yields per a hectare of sown area. When yields are concerned, it is noticeable that Serbia lags behind Croatia and Slovenia. Although they have no more fertile land than Serbia has, on the contrary, those countries manage to realize higher yields. The reasons are higher investments in agriculture. High quality soil cultivation, good preparation of soil before sowing, applies of high quality fertilizers and seeds etc. leads to yield increase. Anyhow, Slovenia is well known by high subsidies for agricultural producers. Investments in modern production and good agrarian policy have affected circumstances that, e.g. yield of maize in Slovenia be almost double than in Serbia. Even more interesting data are those on maize yield in the European Union countries (Belgium 12, Germany 9.8, Austria 8.7, the Netherlands 13 tons per a hectare, etc.). Stagnation of Serbia is significant. As it was already mentioned, soil fertility is the most important factor, and Serbia has very fertile land, especially Vojvodina ("Breadbasket of Europe"). Thus, the problem lies in a proper utilization of land. The role of the state is very important here. By the agrarian policy measures, investments in agricultural production and adequate subsidizing of this production, the state can have an effect on its development and increased competitiveness. In the final part of the paper were mentioned the basic problems of this production nowadays and in that way could perceived which were the main aspects of agricultural production where should be reacted. It is evident that there must work on these problems resolution and that good agrarian policy at the state level is inevitable. Agriculture used to be one of the most significant activities in Serbia, while in that period had produced sufficient products, as for local needs, as well as for export. As it was already said, the land is maybe the most important capacity in agriculture and it is necessary to use those capacities in the best possible way. Thus, Serbia has the capacities for high quality agricultural production, but it remains to be seen whether these capacities will be used in the right way. 


\section{References}

Croatian Bureau of Statistics (CBS) (2013): Statistical Yearbook of Republic of Croatia, pp. 264-266 Available at: www.dzs.hr (01.02.2015.)

FAO (2013): Statistical Yearbook, Available at: www.fao.org,

http://www.fao.org/docrep/018/i3107e/i3107e.PDF (01.02.2015.)

Institute for Statistics B\&H (2012): FB\&H in figures 2012. Available at: www.fzs.ba (03.02.2015.)

Subić, J., Popović, V. Ž., \& Vuković, P. (2005). Održivo korišćenje zemljišta u poljoprivredi. Ekonomika, 51(5-6), 26-35.

Ministry of Agriculture, Forestry and Water Management of Serbia (2010): Serbian National Program of Agriculture 2009-2011

Montenegro Statistical Office (MONSTAT) (2012): Statistical Yearbook 2011 (pp. 104-105) Available at: www.monstat.org (02.02.2015.)

Montenegro Statistical Office (MONSTAT) (2013): Statistical Yearbook 2012. (pp. 91-92) Available at: www.monstat.org (01.02.2015.)

Kljajić, N., Arsić, S., \& Mijajlović, N. (2012). Zemljište kao ekološki faktor poljoprivredne proizvodnje. Tranzicija, 14(29), 38-47.

Rast prognoze za proizvodnju pšenice i kukuruza, septembar 2013, www.agrarije.com (03.02.2015.)

SEEDEV tim (2012): Studija: „Analiza trendova u proizvodnji i trgovini poljoprivrednih Proizvoda iz Vojvodine u odnosu na proizvodnju i trgovinu u Srbiji, regionu, EU $i$ Svetu, Za Program: Fond za promociju izvoza poljoprivrednih proizvoda,, APF redni broj JNMV 19/2012. SEEDEV tim: Goran Živkov, Brankica Obućina, Nemanja Teofilović, Paskal Bernardoni, Ivana Dulić Marković, Danijela Bardić i Miroslav Božić

SORS (2011) Statistical Yearbook of Serbia 2011 (Section: Agriculture, pp 206-208) Available at: www.stat.gov.rs (04.02.2015.)

SORS (2012) Statistical Yearbook of Serbia 2012 (Section: Agriculture, pp 206-208) Available at: www.stat.gov.rs (04.02.2015.)

SORS (2014) Statistical Yearbook of Serbia 2013 (Section: Agriculture, pp. 228-231) Available at: www.stat.gov.rs (04.02.2015.)

State Statistical Office, Republic of Macedonia (SSO) (2014): Statistical Yearbook of Republic of Macedonia, 2014. (Agriculture, pp. 417, 421) Available at: www. stat.gov.mk (02.02.2015.)

Statistical Office of the Republic of Slovenia (SORS) (2013): Statistical Yearbook of the Republic of Slovenia 2013. (pp. 299., 301) Available at: www.stst.si (03.02.2015.)

Todorović, S. Z., \& Munćan, M. P. (2009). Optimiranje strukture setve porodičnih gazdinstava u nestabilnim uslovima poslovanja. Ekonomika poljoprivrede, 56(2), 329-339. 